\title{
Root, Root Hair, and Symbiotic Mutants of the Model Legume Lotus japonicus
}

\author{
Masayoshi Kawaguchi, ${ }^{1,6}$ Haruko Imaizumi-Anraku, ${ }^{2}$ Hiroyuki Koiwa, ${ }^{3}$ Sinobu Niwa, ${ }^{4}$ Akira Ikuta, ${ }^{4}$ \\ Kunihiko Syono, ${ }^{5}$ and Shoichiro Akao ${ }^{2}$ \\ ${ }^{1}$ Department of Life Sciences, Graduate School of Arts and Sciences, University of Tokyo, Komaba 3-8-1, Meguro-ku, \\ Tokyo 153-8902 Japan; ${ }^{2}$ National Institute of Agrobiological Resources, Kannondai 2-1-2, Tsukuba, Ibaraki 305-8602 \\ Japan; ${ }^{3}$ Iwate Biotechnology Research Center, Narita 22-174-4, Kitakami, Iwate 024-0003 Japan; ${ }^{4}$ Science University of \\ Tokyo, 2641 Yamazaki, Noda-shi, Chiba 278-8510 Japan; ${ }^{5}$ Nihon Women's University, Mejirodai 2-8-1, Bunkyo-ku, Tokyo \\ 112-8681 Japan; ${ }^{6}$ PRESTO, Japan Science and Technology Corporation
}

Submitted 1 June 2001. Accepted 26 August 2001.

To gain an overview of plant factors controlling nodule number and organogenesis, an extensive screening using model legume Lotus japonicus was carried out. This screening involved 40,000 M2 seeds, and 32 stable mutant lines were isolated. From these, 16 mutant lines maintaining the phenotypic variation were selected and genetically analyzed. With respect to nodule number, four loci were identified, Ljsym 77, Ljsym 78, slippery root (slp), and radial organization1 (rdo1). The former two mutants have an increased number of nodules, while the latter two have a decreased number. Ljsym78-1 and Ljsym 78-2 are hypernodulating mutants with a branched root system and were found to be allelic to Ljsym16. The phenotype of the Ljsym77 mutant was highly pleiotropic, being deficient in light and gravity responses. The slp mutant was isolated as a low-nodulating mutant lacking root hairs. Concerning nodule organogenesis, nine symbiotic loci were identified, including the two loci alb1 and fen1. Mutants affecting the developmental process of nodule organogenesis were placed in three phenotypic categories: Nod $^{-}\left(\right.$Ljsym 70 to Ljsym73), Hist ${ }^{-}$(alb11, alb1-2, and Ljsym79), and Fix $^{-}$(fen1, Ljsym75, and Ljsym81).

Additional keywords: root development.

The formation of a nitrogen-fixing root nodule is a typical example of postembryonic development regulated by environmental stimuli. For example, Nod factors (lipo-chitooligosaccharides [LCO]) are produced by symbiotic rhizobia and serve as positive regulators of nodule formation and infection (Dénarié et al. 1996; Schultze and Kondorosi 1998; Spaink 1992; Spaink and Lugtenberg 1994). In contrast, ethylene (Heidstra et al. 1997; Penmetsa and Cook 1997) and nitrogen in the form of $\mathrm{NO}_{3}{ }^{-}$and $\mathrm{NH}_{4}{ }^{+}$are negative regulators.

In the last 20 years, extensive studies on the rhizobial genes have resulted in the successful identification and characterization of various kinds of symbiotic genes (Fischer 1994;

Corresponding author: M. Kawaguchi; Department of Environmental Sciences, Faculty of Science, Niigata University, Ikarashi, Ninomachi 8050, Niigata City, Niigata, 950-2181, Japan; Telephone and Fax: +8125-262-6172; E-mail: masayosi@sc.niigata-u.ac.jp

Current address of S. Niwa: Amersham-Pharmacia Japan, 3-25-1 Hyakunincho, Shinjuku, Tokyo 169-0073 Japan.
Gonzalez et al. 1996; Hirsch 1992; Long 1996). To dissect the genetic network underlying the process of nodule organization from the plant side, symbiotic mutants have been isolated from pea (Borisov et al. 1992; Duc and Messager 1989; Jacobsen and Feenstra 1984; Kneen and LaRue 1988; Kneen et al. 1994), soybean (Devine and Kuykendall 1996), common bean (Park and Buttery 1992; 1994), fava bean (Duc 1995; Haser et al. 1992), alfalfa (Dudley and Long 1989), and sweet clover (Caetano-Anolles and Gresshoff 1991; Kneen and LaRue 1988; Stougaard 2001; Suganuma 1999). Characterization of these mutants has revealed the existence of genes responsible for nodule initiation, bacterial invasion, nitrogen fixation, and autoregulation. However, because the tools for molecular genetic analysis of leguminous plants are still in the process of being developed, there has been only one report of the molecular cloning of a symbiotic gene.

In order to establish a more tractable approach to the study of plant genes involved in nodulation, recent studies have used several diploid autogamous legumes as genetic systems. Besides the pea, soybean, and sweet clover models, studies have been initiated on Lotus japonicus as a determinate-nodulation host (Handberg and Stougaard 1992) and Medicago truncatula as an indeterminate nodulation host (Barker et al. 1990; Cook 1999). In L. japonicus, transformation procedures via either Agrobacterium tumefaciens or A. rhizogenes, or both, have been published (Martirani et al. 1999; Handberg et al. 1994; Oger et al. 1996; Stiller et al. 1997). In Medicago truncatula, symbiotic mutants and natural variants have been reported and characterized (Bénaben et al. 1995; Catoira et al. 2000; Penmetsa and Cook 1997; Sagan et al. 1995; Tirichine et al. 2000). The infrastructure of a genome analysis has been developed by several researchers (Jiang and Gresshoff 1997; Kawaguchi et al. 2001; Men et al. 2001; Sandal and Stougaard 1998). In parallel with these studies, symbiotic mutants deficient in rhizobial and mycorrhizal associations have been isolated and characterized (Hayashi et al. 2000; Stougaard 2001) for nodulation (ImaizumiAnraku et al. 1997, 2000; Schauser et al. 1998; Szczyglowski et al. 1998; Wopereis et al. 2000) and for mycorrhization (Bonfante et al. 2000; Senoo et al. 2000; Solaiman et al. 2000; Wegel et al. 1998). Noteworthy is the $A c$ transposon tagging that was developed for L. japonicus (Thykjær et al. 1995). From this, the molecular cloning of the symbiotic gene Nin, which is responsible for nodule inception (Schauser et al. 1999), was carried out.

To obtain an overview of factors that are controlled by the plant genome, an extensive screening of mutants affecting nod- 
ule number and organogenesis was conducted using the model legume L. japonicus.

\section{RESULTS}

\section{Isolation of mutants affecting nodule number and organogenesis.}

L. japonicus 'Gifu' B-129 seeds $(8,000)$ treated with $0.4 \%$ ethylmethane sulphonate (EMS) were sown and germinated in a greenhouse setting. M2 seeds were collected from approximately 3,000 M1 plants. Screening of 40,000 M2 seeds (10 seeds per seed family) enabled the isolation of 32 mutant lines with phenotypes that were stably inherited up to the M4 and M6 generations. The mutants were divided into two classes, root and root hair mutants affecting the number of effective nodules (5 mutant lines) and symbiotic mutants affecting nodule organogenesis (27 mutant lines). In the root and root hair mutants class, we identified two loci that conferred an increased number of nodules when mutated (Ljsym77 and Ljsym 78) and two loci that produced fewer nodules (slippery root $[\mathrm{slp}]$ and radial organization $1[\mathrm{rdol}])$. Allelism tests were also carried out using 11 representative mutants out of the total 27 symbiotic mutants. Nine loci affecting nodule organogenesis (Ljsym70 through Ljsym76, Ljsym79, and Ljsym81) were subsequently identified including albl and fenl, which had been previously reported by Imaizumi-Anraku and associates (1997). Phenotypic traits of 16 mutants, except Ljsym79, were segregated as monogenic recessives (Table 1).

\section{Root and root hair mutants affecting nodule number.}

Enhanced nodulation mutant, Ljsym77. The Ljsym 77 mutant was isolated by screening on agar plates. The number of nodules observed on the roots of the Ljsym 77 mutant grown on agar plates was two to three times greater than that on wildtype plants (Fig. 1B and C). The zone of nodule differentiation in the Ljsym 77 mutant was wider than that of wild type (Fig. $1 \mathrm{~B}$ and $\mathrm{C}$ ). In contrast to typical hypernodulating mutants, the Ljsym 77 mutant phenotype is highly pleiotropic. When grown on agar plates in the absence of bacteria, the hypocotyls and shoots of the Ljsym77 mutant were longer than those of wild type. In addition, the lateral roots grew in a nearly horizontal direction (Fig. 1A). Furthermore, the root and hypocotyl of the mutant were thinner than those of wild type (data not shown). When illuminated with white light, the surfaces of wild-type nodules and roots turned green (Fig. 1B), whereas those of the Ljsym 77 mutant did not (Fig. 1C), indicating that the root is also defective in light response. Although the Ljsym77 plant was not as strong as the hypernodulating mutants, it was selfsupporting when the seedlings were placed on the agar plate.

Hypernodulating mutants with a branched root system, LjSym78. Two mutants, Ljsym78-1 and Ljsym78-2, were isolated as hypernodulating mutants with a highly branched root system. When the mutant seedlings were grown in vermiculite immersed with bacteria-free B \& D medium (Broughton and Dilworth, 1971) containing $0.5 \mathrm{mM}$ potassium nitrate, the numbers of lateral roots in the Ljsym78-1 and Ljsym78-2 mutants were 3.2 and 1.7 times greater than those in wild-type seedlings, respectively (Fig. 2A and B). The primary roots of both mutant seedlings were shorter than wild-type roots (Fig. 2A). When Mesorhizobium loti JRL501 bacteria was inoculated onto the roots, the growth of the Ljsym 78 seedlings was severely inhibited compared with wild-type growth (Fig. 2C), due to excessive nodule formation. The Ljsym78-1 mutant seedlings developed approximately two times more nodules than Ljsym 78-2 under various concentrations of potassium nitrate (Fig. 2D). From the dose-response analysis of nitrate on

Table 1. Sixteen representative mutants of Lotus japonicus affecting nodule number and organogenesis ${ }^{\mathrm{a}}$

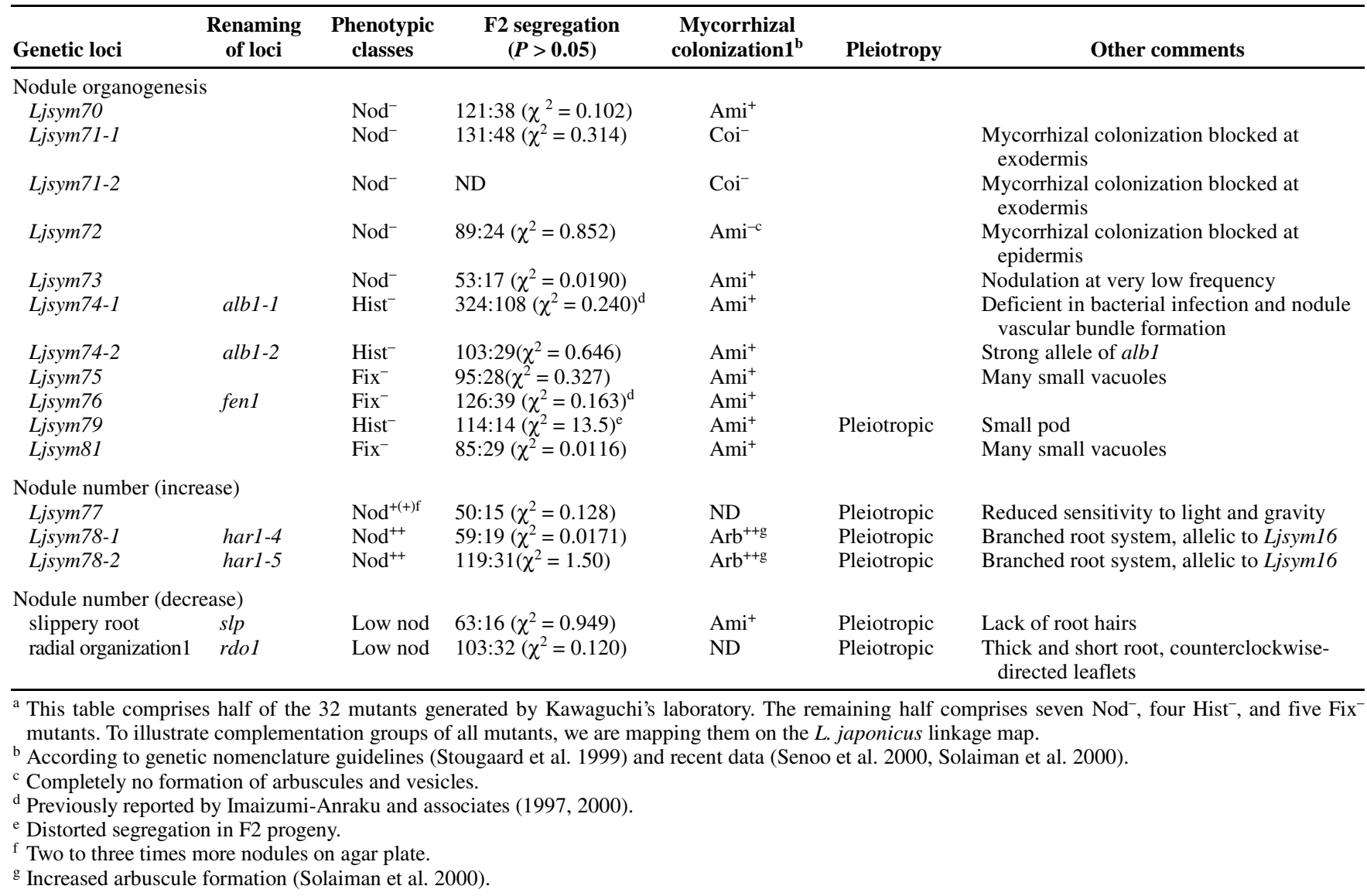


nodule development, Ljsym78-1 and Ljsym78-2 mutants appear to be tolerant to $3 \mathrm{mM}$ potassium nitrate (Fig. 2D). However, higher concentrations of nitrate significantly inhibited the development of Ljsym78-1 and Ljsym78-2 nodules but not the formation of nodule primordia (data not shown). Unexpectedly, the tendency seemed to be similar in both wild and mutant types (Fig. 2D). In contrast to nodulation, the number of lateral roots in the wild type and the Ljsym 78 mutants was apparently not suppressed by higher concentrations of potassium nitrate (data not shown). The phenotype of the Ljsym 78 mutants is very similar to that of the harl-1 and its allele Ljsyml6 mutants reported previously (Schauser et al. 1998; Szczyglowski et al. 1998; Wopereis et al. 2000). Allelism tests revealed that Ljsym78-1 and Ljsym78-2 are allelic with Ljsym 16, indicating that they are harl-4 and harl-5 respectively (data not shown).

Root hair mutant, slp. The slp mutant, a low-nodulating mutant, was isolated by careful screening on agar plates. Microscopic observation of the slp mutant revealed that the root almost completely lacks root hairs (Fig. 3A and B). The slp mutant could grow as well as wild type in spite of the lack of root hairs; a trait that differs from the root-hairless mutants of Arabidopsis, which are all seedling lethal (Schneider et al. 1997). When the slp seedlings were pulled out of the agar, the roots came out easily without breaking due to the lack of root hairs, which, if present, would keep the roots entrenched within the agar. Upon inoculation with $M$. loti, bacteria could be seen colonizing the slp even though very few root hairs were present. Moreover, once bacteria entered the root cells, nodules developed normally. (Fig. 3C and D). This is the first example found in legumes of a low-nodulating mutant deficient in the development of root hairs.

Mutant affecting radial organization, rdo1. The rdol mutant was isolated as a low-nodulating mutant with aberrant radial organization. The L. japonicus rdol mutant exhibited the thickand short-root phenotype (Fig. 4A). Shoots of the rdol mutant were also thicker and shorter than those of wild type. These phenotypes are similar to those shown by sym17, a pleiotropic mutant of pea (Kneen et al. 1994). Transverse sections of the primary root $1 \mathrm{~cm}$ distal to the root tip revealed that the cell number and the volume of the primary root of the mutants were greater than those of the wild-type root, especially in the root cortex (Fig. 4B and C). Interestingly, leaflets from the rdol mutant originated from the shoot tip in a counterclockwise direction when the seedling was observed from above (Fig. 4D and E).

\section{Developmental and infectious pathways to an effective nodule.}

Mutants affecting the developmental process of nodule organogenesis were placed in three phenotypic categories: $\mathrm{Nod}^{-}$ (Ljsym70 to Ljsym73), Hist $^{-}$(alb1-1, alb1-2, and Ljsym79), and Fix $^{-}$(fen1, Ljsym75, and Ljsym81). Hist ${ }^{-}$is a mutant category used to represent defects in 'cooperative histogenesis' elicited by symbiotic interactions, and it is defined as the stage between $\mathrm{Nod}^{-}$and $\mathrm{Fix}^{-}$. Fix ${ }^{-}$is defined as a mutant category with ineffective nodules irrespective of the presence of many infected cells.

\section{Nod $^{-}$mutants.}

Four genes were identified from allelism tests using five Nod $^{-}$mutant lines. Genes Ljsym70, Ljsym71-1, Ljsym71-2, and Ljsym 72 were nonnodulating $\left(\mathrm{Nod}^{-}\right)$, but very small bumps on the Ljsym 70 root were induced after prolonged incubation with M. loti TONO and JRL501 strains. In contrast, the Ljsym73 gene elicited effective, large nodules at a very low frequency. Among these mutants, no clear strain specificity could be observed. $\mathrm{Nod}^{-}$phenotypes can be due either to a mutation in Nod-factor signaling or the lack of nod-gene inducers secreted from the root. To distinguish between these two possibilities, we utilized $M$. loti JRL501 and TONO strains carrying the plasmid pMP2112, which produces Nod factor in response to the nod-gene inducer naringenin. Production of Nod factors was confirmed by high-pressure liquid chromatography analysis with an octyldecyl silane column after the application of naringenin at a concentration of $10^{-7} \mathrm{M}$ (Niwa et al. 2001). Inoculation of roots with $M$. loti JRL501 pMP2112 in the pres-
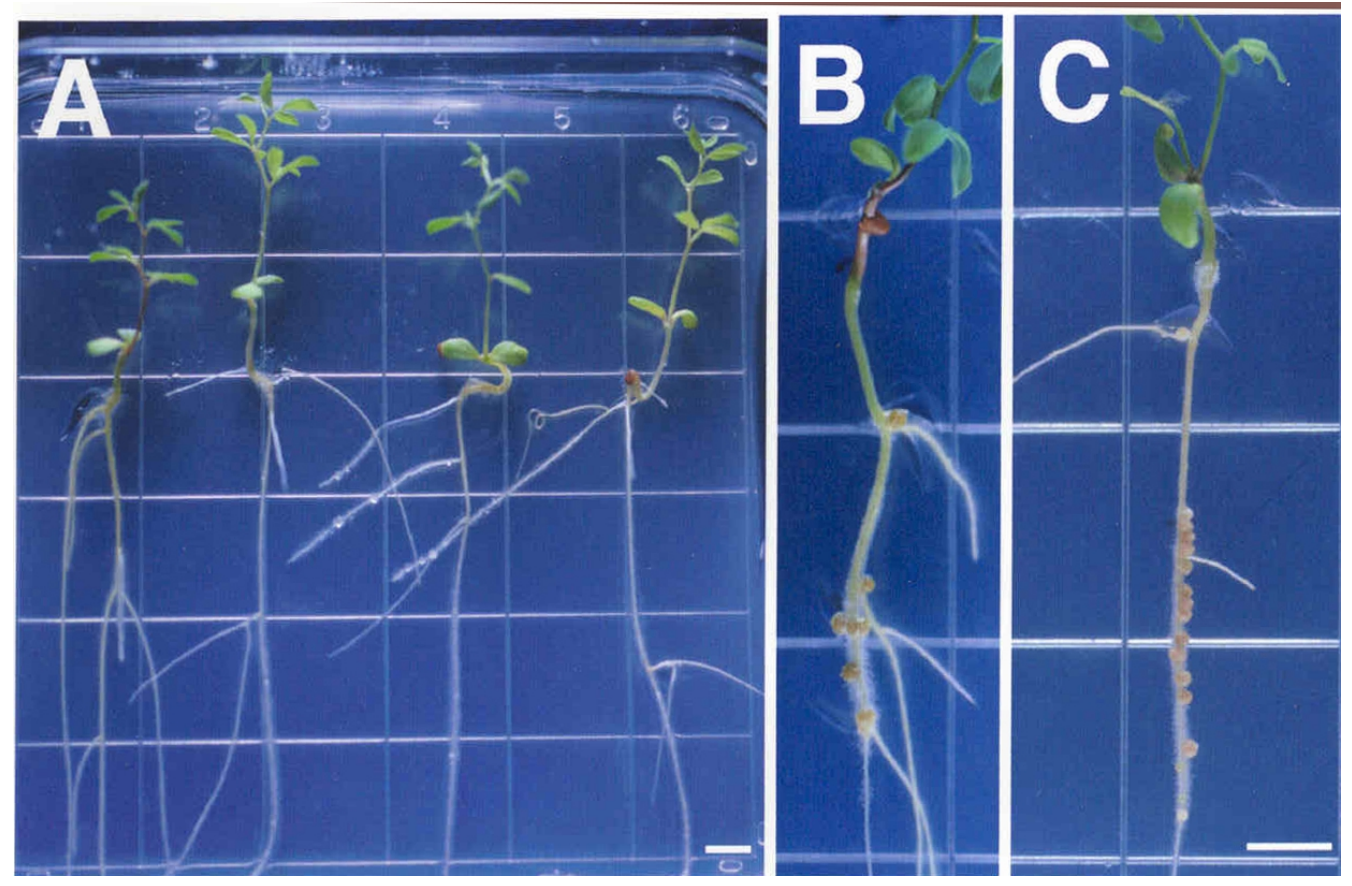

Fig. 1. Phenotypes of the Ljsym 77 mutant grown on an agar plate. A, Wild-type (left) and Ljsym 77 mutant seedlings (third from the right) in the absence of Mesorhizobium loti. B, Wild-type and Ljsym 77 mutant (right) seedlings 31 days after inoculation with M. loti JRL501. C, Seedlings of the Ljsym77 mutant 31 days after inoculation with $M$. loti JRL501. Note that the zone of nodule development is wider than in the Ljsym77 mutant seedling. Bars $=5 \mathrm{~mm}$. 

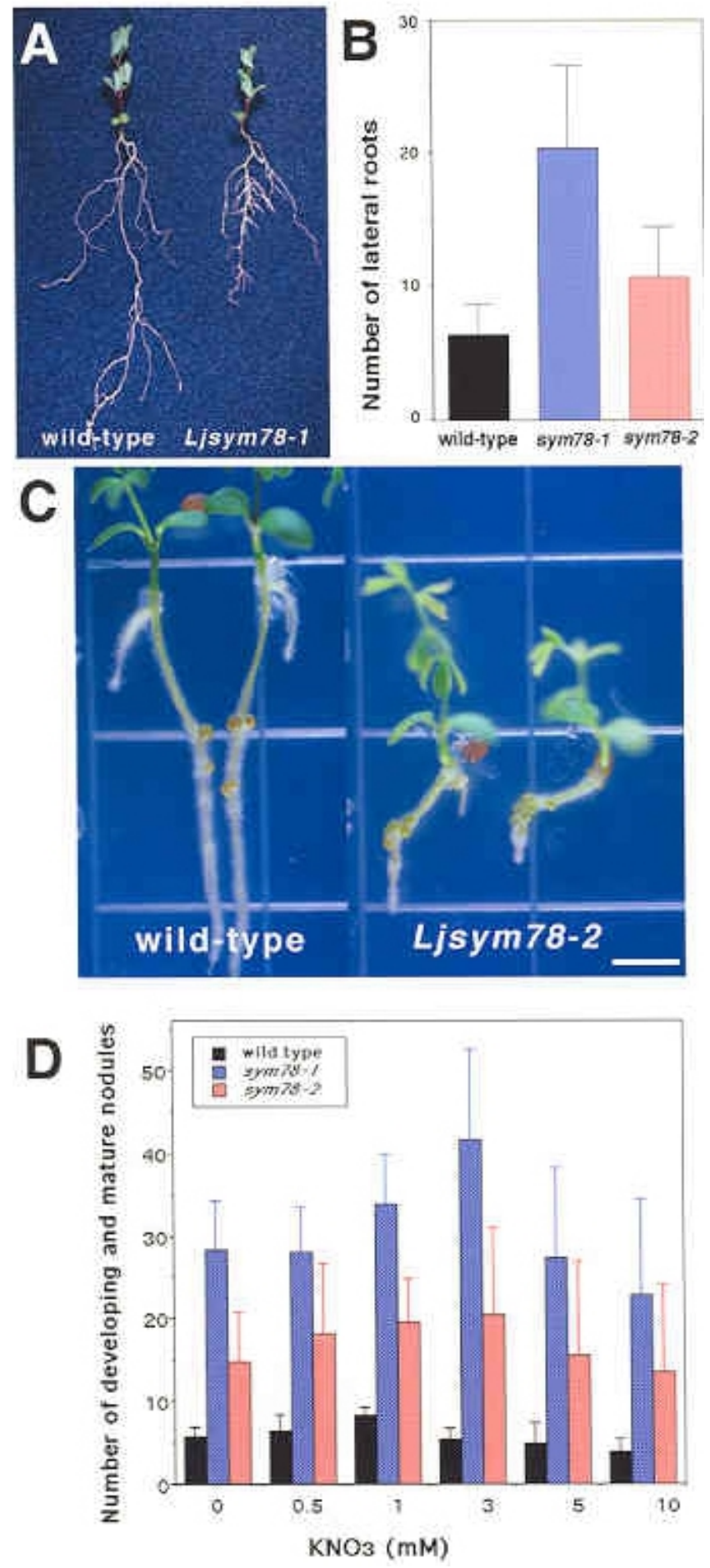

Fig. 2. Phenotypes of the hypernodulating mutants. A, Seedlings of wild type (left) and Ljsym 78-1 mutant (right) with branched root system. The seedlings were grown in vermiculite immersed with bacteria-free B \& D medium (Broughton and Dilworth 1971) containing $0.5 \mathrm{mM}$ potassium nitrate for 3 weeks. B, Number of lateral roots in the bacteria-free seedlings. Lateral roots were counted 3 weeks after germination. C, Appearance of seedlings on agar plate containing B \& D medium 17 days after inoculation with Mesorhizobium loti JRL501. Wild type is on the left, and the LjSym 78-2 mutant is on the right. Bar $=5 \mathrm{~mm}$. D, Effects of potassium nitrate on nodule number in wild-type and Ljsym 78 seedlings. Small developing and mature nodules were counted 3 weeks after inoculation with M. loti MAFF 303099. Mean values with standard deviations were obtained from at least seven seedlings. ence of naringenin did not overcome the $\mathrm{Nod}^{-}$phenotype, indicating that the $\mathrm{Nod}^{-}$phenotype of Ljsym70 to Ljsym73 mutants is not due to the absence of nod-gene inducers. The four loci were further differentiated by the phenotypic characterization of mycorrhizal colonization (Table 1) (Senoo et al. 2000). The Ljsym71-1, Ljsym71-2, and Ljsym72 genes are mycorrhizal mutants, while Ljsym70 and Ljsym73 are not, indicating that the former three genes are part of a common signaling pathway between rhizobia and mycorrhiza, whereas the latter two genes are required specifically for rhizobial interaction.

\section{Hist ${ }^{-}$mutants.}

The alb1-1 (Ljsym74-1) mutant was previously reported as an ineffective mutant deficient in successful bacterial entry (Imaizumi-Anraku et al. 1997) and development of nodule vascular bundles, concomitant with strong suppression of ENOD40 gene expression (Imaizumi-Anraku et al. 2000). In the alb1-1 nodule, bacteria often failed to enter the host cells and, consequently, resided in intercellular spaces in the nodule (Fig. 5A). Possible necrotic patches were also observed on the alb1-1 nodule surface (Fig. 5C).

From genetic analysis of the Hist ${ }^{-}$mutants, we found another allele of the alb1 mutant, alb1-2. At an early stage, the phenotype of the alb1-2 mutant was indistinguishable from that of a Nod $^{-}$mutant. Three weeks after inoculation, the albl-2 mutant elicited nodulelike structures on the root (Fig. 5B and D). Histological characterization revealed that the nodulelike structure was made of a nodule primordium but lacked nodule vascular bundles, a differentiated nodule endodermis, and a bacterial infection zone (Fig. 5B). When inoculated with $M$. loti JRL507 containing a gusA gene, few infection events were observed in the alb1-2 roots 22 days after inoculation (Fig. 5D), while bacteria colonized in the intracellular space of alb11 nodules (Fig. 5C). The phenotype of the albl mutants resembles that of the Ljsym8 mutant reported by Schauser and associates (1998). Allelism tests found albl to be distinct from Ljsym8.

The Ljsym79 mutant induced nodulelike structures on roots at a low frequency. Infection of $M$. loti JRL501 was severe (data not shown). In addition, the pods of the Ljsym79 plant were smaller than those of wild-type plants, even when the mutant was grown in nutrient-rich soil. The Ljsym79 mutant was backcrossed twice, but the inheritance of the mutant phenotype was distorted in the F2 population and did not fit typical Mendelian ratios (Table 1). The Ljsym79 mutant appeared to be a pleiotropic mutant that affects both nodule organogenesis and pod development.

\section{Fix ${ }^{-}$mutants.}

The nodules of wild type and three ineffective mutants were compared 22 days after inoculation. Brightfield microscopy of longitudinal sections of the wild-type nodule revealed enlarged infected cells packed with bacterial endosymbionts in the central zone of the nodule (Fig. 6A). In contrast, many small vacuoles were clearly visualized in the infected cells of the Ljsym75 nodules prior to maturation (Fig. 6B). Many vacuoles were also observed in the infection cells of the Ljsym81 nodules (data not shown). However, in the fenl mutant, which had been reported as an ineffective mutant enlarging infected cells (Imaizumi-Anraku et al. 1997), no prominent accumulation of small vacuoles was found in infected cells (Fig. 6C). In place of vacuoles, granulelike structures were observed in several infected cells of the fenl nodule (Fig. 6C). In order to monitor the colonization of symbionts, we used M. loti JRL507, which is marked with gusA. Upon inoculation of wild-type roots with M. loti JRL507, a blue color was found in nodules throughout development (Fig. 6D). Interestingly, in the Ljsym75 and fenl 
mutants, a blue color was observed in developing nodules but not in fully formed nodules (Fig. 6E and F).

Finally, a summary of the symbiotic mutants affecting nodule organogenesis is found in Figure 7.

\section{DISCUSSION}

\section{Defects in root and root hair development} affect nodule number.

The results of this study indicate that the mutant Ljsym77 is highly pleiotropic with enhanced nodulation. The hypocotyls and shoots of the Ljsym 77 mutant were longer than those of the wild type. The lateral roots of the Ljsym 77 mutant grew in a nearly horizontal direction (Fig. 1A). When illuminated with white light, the surfaces of wild-type roots turned green (Fig. 1B), whereas those of the Ljsym 77 mutant did not (Fig. 1C). These features exhibited by the L. japonicus Ljsym 77 mutant are reminiscent of those shown by the Arabidopsis hy5 mutant that is deficient in a variety of responses, including light-dependent hypocotyl elongation and gravitropism (Oyama et al. 1997). Interestingly, the hy5 mutant elicits enhanced lateral root formation. The HY5 gene has been isolated by T-DNA tagging and shown to encode a transcriptional factor with a bZIP motif (Oyama et al. 1997). The unphosphorylated isoform of the HY5 gene product in Arabidopsis strongly prevents the generation of lateral roots, suggesting that the phosphorylation of the HY5 protein regulates lateral root formation (Hardtke et al. 2000). This information leads us to speculate that the Ljsym 77 mutant may encode an HY5 homolog and act as a regulator of nodule initiation in place of lateral root formation. A detailed characterization of the Ljsym 77 mutant and the molecular cloning of the gene responsible for the pleiotropic mutant phenotype will be published later.

The Ljsym78-1 and Ljsym78-2 mutants were isolated as hypernodulating mutants with a branched root system. It was found that the branched system was formed by the restriction of primary root growth and the promotion of lateral root formation (Fig. 2A and B). This root system was also prominent in the absence of $M$. loti. Since these phenotypes resemble $L$. japonicus harl hypernodulating mutants (Wopereis et al. 2000), the Ljsym 78-1 and Ljsym 78-2 mutants were reciprocally crossed with Ljsym16, an allele of the harl locus, harl-3. As a result, our Ljsym78-1 and Ljsym78-2 mutants were found to be allelic to Ljsym16, named harl-4 and harl-5 respectively. Analysis of the effects of nitrate on nodule number showed that both mutants seemed to be tolerant of up to $3 \mathrm{mM}$ of potassium nitrate. Contrary to our expectation, nodule formation on the Ljsym 78-1 and Ljsym78-2 roots was apparently suppressed by the application of 5 or $10 \mathrm{mM}$ of potassium nitrate, although the formation of nodule primordia was not inhibited by high concentrations (Fig. 2D). The tendency seemed to be similar in both wild type and mutants. Therefore, detailed physiological analysis (for example, the analysis of the effects of nitrogen compounds on nitrogen-fixation activity as well as nodule formation) will be required to reveal the relationship between the hypernodulation phenotype of harl mutants and nitrate tolerance. Wopereis and associates (2000) have reported that nodule morphogenesis on harl-1 mutant plants was insensitive to 5 to $15 \mathrm{mM}$ of combined nitrogen. Although we did not examine the effects of nitrogen compounds under the same conditions, the different responses to nitrate among alleles suggest that harl-1 may be the strongest allele of this locus. Recently, a mutation in the Ljsym 78 locus has been shown to enhance mycorrhiza formation and arbuscule differentiation (Solaiman et al. 2000), suggesting that the LjSym 78 gene product negatively regulates mycorrhiza formation as well as lateral organ development.
Radial organization of the root is important for nodule formation, because the location of the cell divisions for the development the nodule primordium is highly restricted. For example, in a determinate-nodule host, cell divisions leading to nodule primordia formation are initiated in the outer cortex, whereas in an indeterminate-nodule host, they take place in the inner cortex (Hirsch 1992). The rdol mutant with its decreased number of nodules is not a symbiotic mutant per se, but rather, a root mutant. The increased number and volume of cortical cells in the roots of the rdol mutant is correlated with a decrease in the efficiency of nodule formation. In contrast, the root of the harl mutant, which shows a dramatic increase in nodule number, is thinner and shorter than the wild-type root. A short and thin root was shown to be due to a reduced number or volume of cells in the radial orientation (Wopereis et al. 2000). The root of the Ljsym77 mutant is both thinner and longer than wild-type roots. An increase in nodule number may correlate with the formation of thin roots.

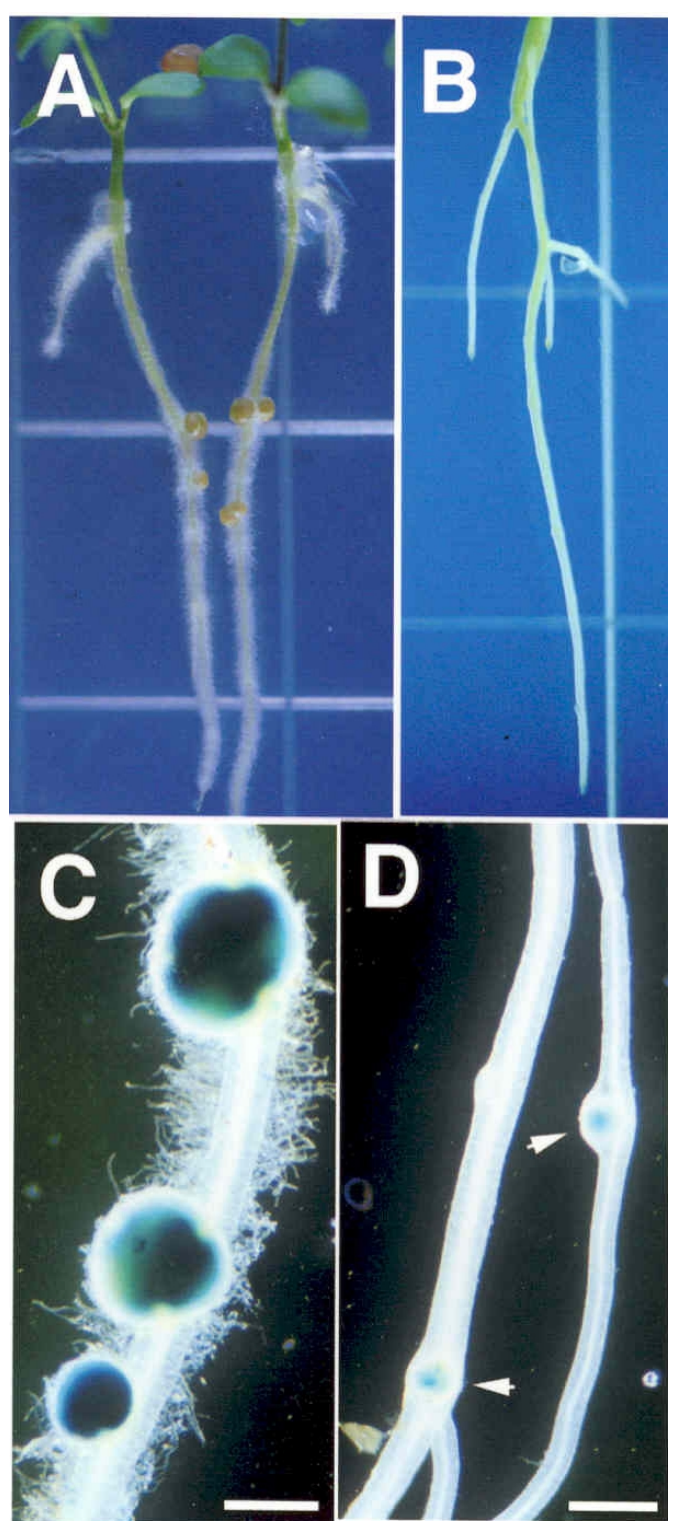

Fig. 3. Phenotypes of the slp mutant. A and B, Roots of seedlings two weeks after inoculation with Mesorhizobium loti JRL501. A, Wild type. B, slp mutant. C and D, Colonization of M. loti JRL507 carrying the gusA gene. C, Wild type; D, slp mutant. Arrowheads indicate colonization of M. loti JRL507 on nodule primordia. Bars $=1 \mathrm{~mm}$. 

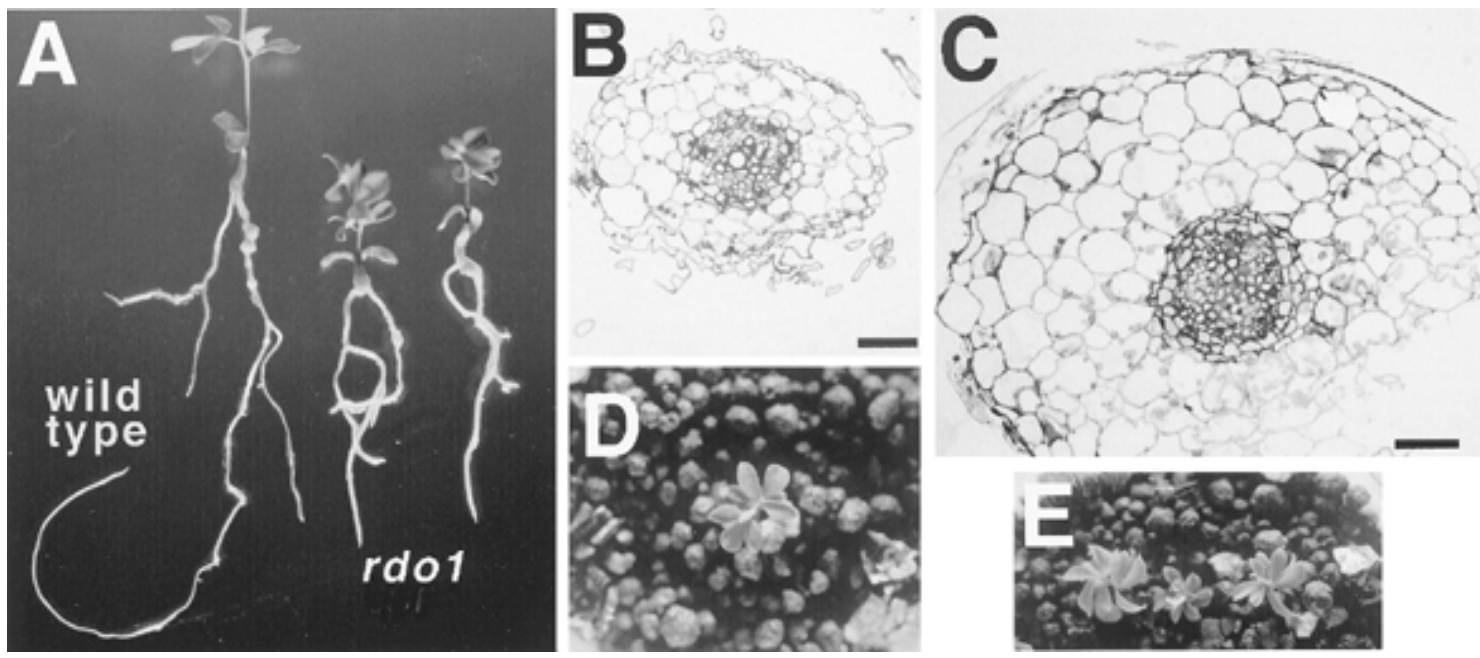

Fig. 4. Phenotypes of the $r d o 1$ mutant. A, Seedlings of wild type (left) and $r d o 1$ mutants (two plants on the right) 22 days after inoculation. B and C, Transverse sections of primary root $1 \mathrm{~cm}$ above root tips. B, Wild type; C, rdol mutant. Bars $=50 \mu \mathrm{m}$. D and E, Seedlings observed from above. D, Wild type; $\mathbf{E}, r d o 1$ mutant. Note that leaflets of $r d o 1$ mutant are generated in the counterclockwise direction.
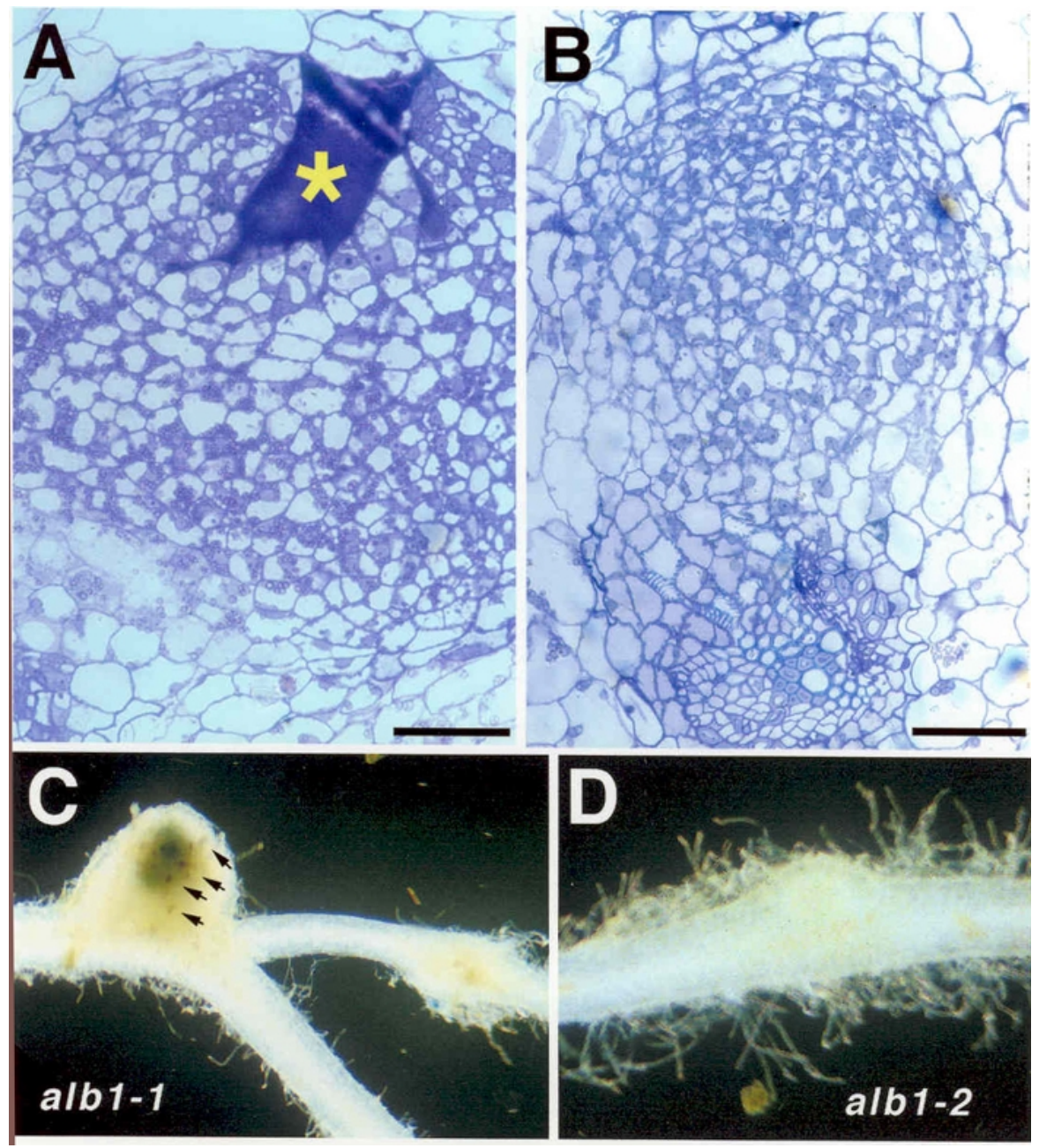

Fig. 5. Phenotypes of the alb1 mutants. A and B, Longitudinal sections of nodulelike structures 22 days after inoculation. A, alb1-1; B, alb1-2. Asterisk indicates bacteria remaining in intercellular space. Bars $=50 \mu \mathrm{m}$. C and D, Colonization of Mesorhizobium loti JRL507 carrying the gusA gene. C, alb1-1 nodule. Arrowheads indicate possible necrotic patches. D, alb1-2 nodule primordium. 
The significance of the root hair for nodulation was demonstrated by the isolation of the slp mutant, which was almost hairless. Nevertheless, bacterial colonization of the root, and even nodule formation, was not completely inhibited in this mutant (Fig. 3D). Careful observation of the early stages of infection should provide new insights into bacterial entry and nodule formation.

\section{Cooperative histogenesis leading}

to a nitrogen-fixing nodule.

Until now, symbiotic mutants incapable of forming effective nodules have been divided into two categories, $\mathrm{Nod}^{-}$and $\mathrm{Fix}^{-}$. In this case, Fix ${ }^{-}$phenotypes include small bumps, bumps, nodulelike structures, and outgrowths, as well as ineffective nodules containing infected cells. When arranged according to the phenotypic variation of the symbiotic mutants, it was not always easy to distinguish between $\mathrm{Nod}^{-}$and $\mathrm{Fix}^{-}$. For example, a wild-type seedling elicits effective nodules 3 weeks after inoculation, while the alb1-2 mutant induces only small nodulelike structures (Fig. 5B and D). The early stages of the albl2 and Ljsym79 mutants were indistinguishable from those of $\mathrm{Nod}^{-}$mutants. In contrast, we believe that it would be feasible to divide the Fix $^{-}$category into an infectious process accompanied by cooperative histogenesis and a functional process exhibiting symbiotic nitrogen fixation. The former produces a nodulelike structure lacking a developed infection zone consisting of infected and uninfected cells, whereas the latter causes the development of an infection zone. In this report, the former mutants are placed into a category named Hist ${ }^{-}$. Judging from the definition, the alb1-1 mutant, which is defective in tissue differentiation such as nodule vascular bundles and bacterial infection (Imaizumi-Anraku et al. 1997, 2000), is a typical Hist ${ }^{-}$mutant, and the alb1-2 and Ljsym79 mutants can also be placed in this category. In contrast, the Fix ${ }^{-}$category is defined as having symbiotic mutants with ineffective nodules irrespective of the presence of many infected cells, and therefore, fen1, Ljsym75, and Ljsym81 can be placed into the Fix category.

Possible necrotic patches were conspicuous on the albl-1 nodule surface (Fig. 5C). The cell is reminiscent of brown cells elicited by abortive infection during the Sinorhizobium meliloti-alfalfa symbiotic interaction (Vasse et al. 1993). Although it is unclear whether the brown patches are related to abortive infection of $M$. loti, it is important to characterize the alb1-1 mutant according to the plant defense response.

\section{Nod $^{-}$mutants and $\mathrm{Fix}^{-}$mutants.}

The phenotype of the Ljsym70 to Ljsym73 mutants was not overcome by inoculation of their roots with $M$. loti JRL501 pMP2112 in the presence of naringenin. This result indicates that the $\mathrm{Nod}^{-}$phenotype appears to be unrelated to the absence of nod-gene inducers. It seems possible that the nonnodulating phenotype of the $\mathrm{Nod}^{-}$mutants is caused by a mutation in Nod factor recognition and subsequent signaling. Recently, LCO were purified from the culture of $M$. loti strains and major
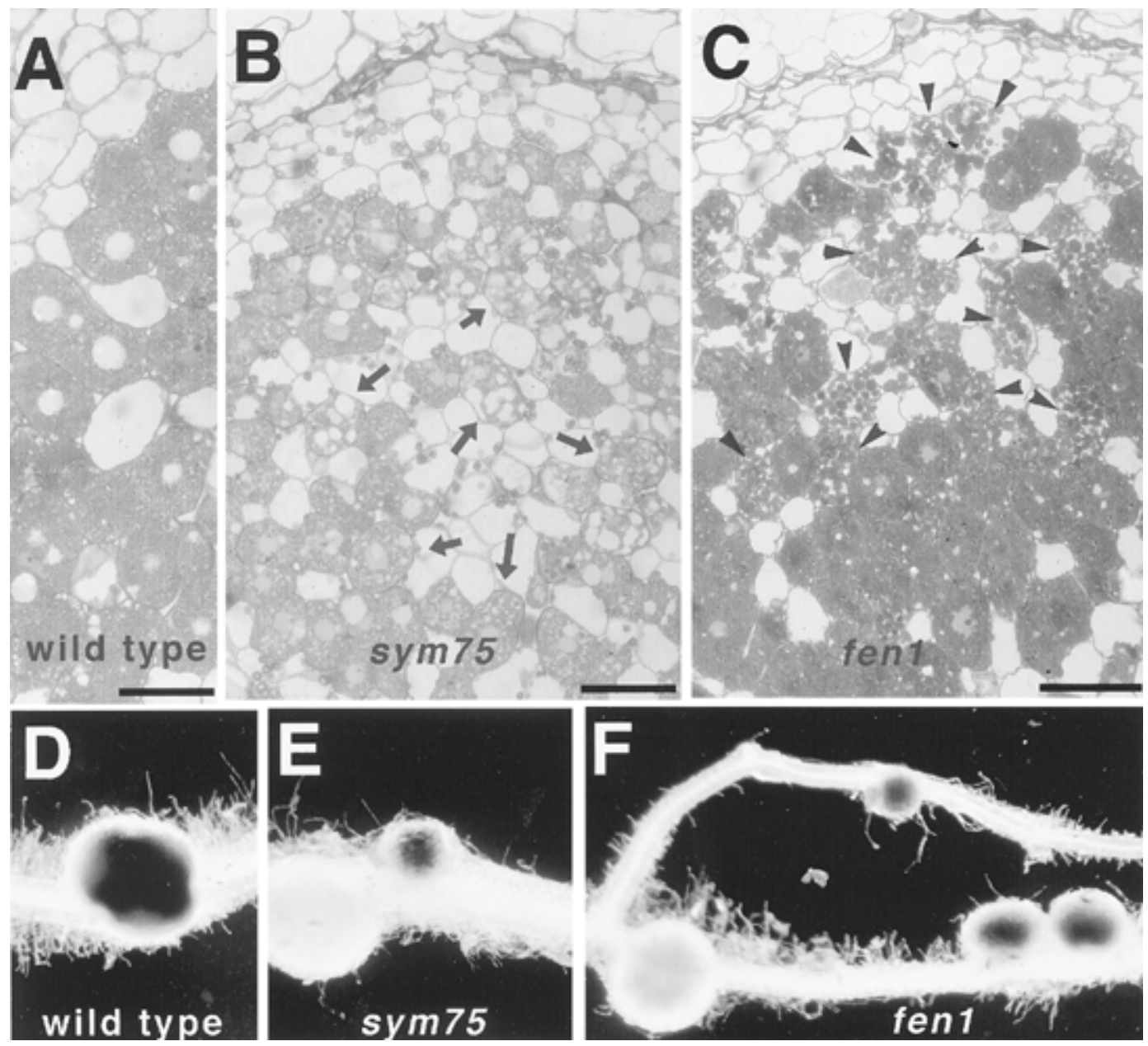

Fig. 6. Histological characteristics of two Fix ${ }^{-}$mutants. A to C, Longitudinal sections of nodules 22 days after inoculation with Mesorhizobium loti JRL501. A, Wild type. B, Ljsym75. Arrows indicate infected cells containing many vacuoles. C, fen1. Arrowheads indicate infected cells having granulelike structures. Bars $=50 \mu \mathrm{m}$. D to F, Colonization of $M$. loti JRL507 carrying the gusA gene 3 weeks after inoculation. D, Wild type; E, Ljsym 75 ; F, fenl. 
components were identified (López-Lara et al. 1995; Niwa et al. 2001). Nodule primordia, together with the expression of LjENOD4O and LjENOD2, could be efficiently induced by the application of LCO (Niwa et al. 2001). The purified LCO could be used to assess the sensitivity of $\mathrm{Nod}^{-}$mutants. Equally, it would be worthwhile to examine the effect of LCO on Hist ${ }^{-}$and $\mathrm{Nod}^{++}$mutants.

In the Ljsym 75 and fen 1 mutants, a blue color indicating colonization of $M$. loti JRL507 was observed in developing nodules but not in fully formed nodules (Fig. 6E and F). Histological analysis revealed that infected cells were highly vacuolated in the Ljsym75 nodule (Fig. 6B), whereas granulelike structures were observed in the infected cells of the fen 1 nodule (Fig. 6C). As reported previously, highly vacuolated, infected cells are the most typical phenotype of premature senescence in ineffective nodules. For example, Morzhina and associates (2000) described how infected cells of pea sym32 mutants were heavily vacuolated and rapidly destroyed. Without vacuolation, however, disintegration of the cytoplasm was advanced in the infected cells of sym26, sym27, and RisFixN mutant lines. To address the question of which Lotus mutants phenotypically correspond to these pea ineffective mutants, more detailed characterization of the Ljsym75, Ljsym81, and fen1 mutants will be required.

Determining the order of the mutant loci in L. japonicus.

The aim of this study was to obtain an overview of the mutational spectrum of $L$. japonicus relative to nodule number and organogenesis through an extensive screening of mutants. From this study, we discovered several novel mutants. However, due to the presence of numerous symbiotic mutants (Schauser et al. 1998; Szczyglowski et al. 1998), we did not carry out complete allelism tests among all mutants. As long as the symbiotic loci are unmapped, it will take a long time to identify the new locus responsible for nodule number and organization. Recently, an early flowering $L$. japonicus 'Miyakojima' MG-20 has been shown to be a suitable crossing partner of a standard 'Gifu' B-129 (Kawaguchi 2000; Kawaguchi et al. 2001). A high-density linkage map is currently being constructed using the F2 population derived from a cross between 'Gifu' and 'Miyakojima'. Similar linkage maps have also been constructed using L. filicaulis (Sandal and Stougaard 1998) or L. japonicus 'Funakura' (Jiang and Gresshoff 1997) as a crossing partner of 'Gifu' B-129. These mapping strategies will allow us to order the many mutant loci in $L$. japonicus.

\section{MATERIALS AND METHODS}

Plant materials and bacterial strains.

Seeds of L. japonicus 'Gifu' B-129 were used as the parental line. For the symbiont, we used the $M$. loti JRL501 strain, a nalidixic acid-resistant variant of $M$. loti MAFF 303099 (National Institute of Agrobiological Resources [NIAR], Tsukuba, Japan) (Imaizumi-Anraku et al. 1997), the TONO strain (a wild symbiont isolated from a Japanese accession of L. japonicus, MG-10 'Tono'), and the NZP2235 strain. These strains, which have good nodule-forming ability, were cultured in tryptone-yeast extract medium at $28^{\circ} \mathrm{C}$ and maintained on yeast extract-mannitol agar plates at $4^{\circ} \mathrm{C}$.

The plasmid pMP2112, which contains the nodD gene of Rhizobium leguminosarum bv. trifoli (López-Lara et al. 1995), was introduced into $M$. loti JRL501 from Escherichia coli KMBL1164 by a triparental mating. M. loti JRL507 containing

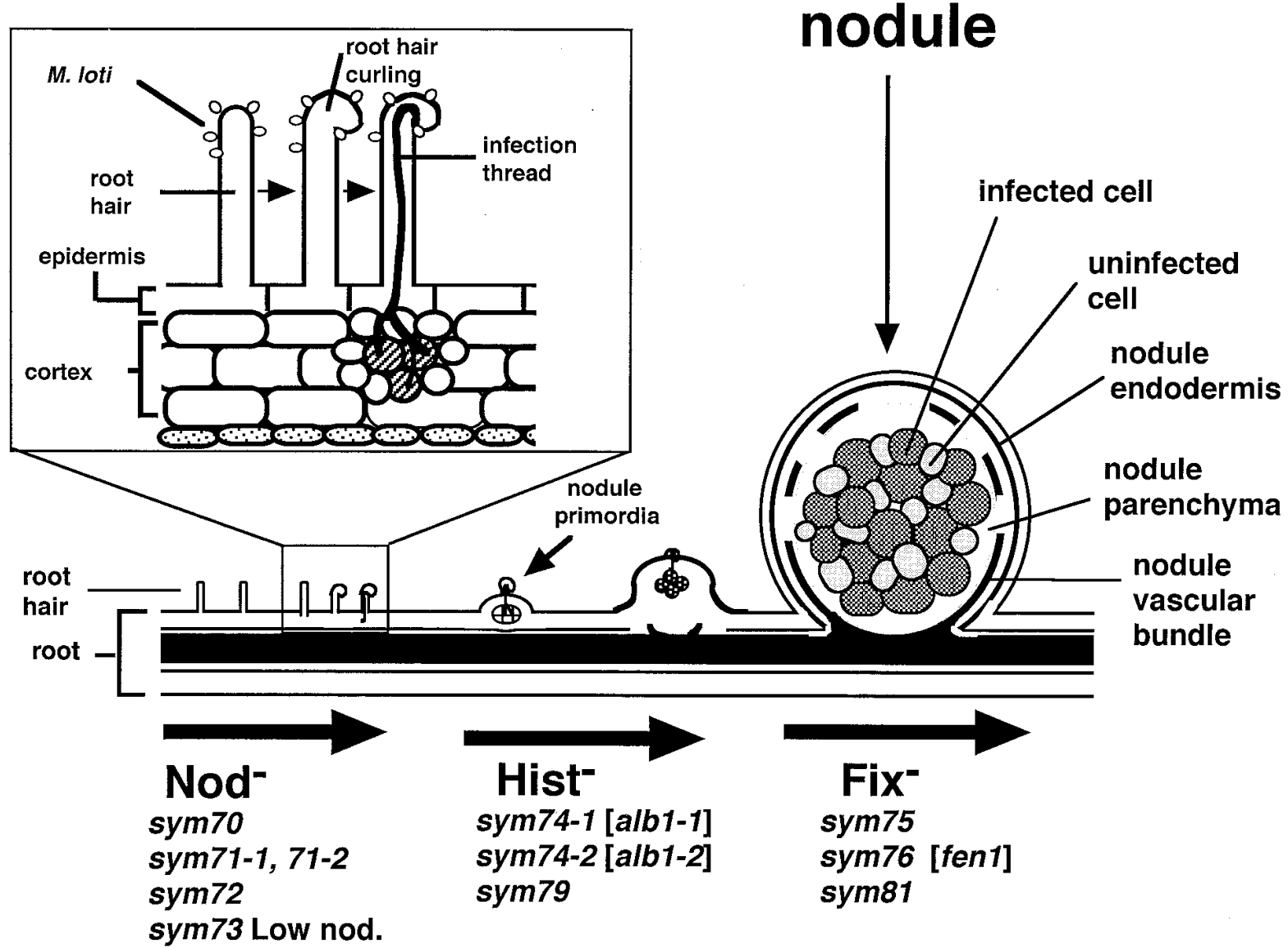

Fig. 7. Summary of symbiotic mutants affecting nodule organogenesis. 
a constitutive gusA expression construct was obtained by introducing pmTn5SSgusA20 from E. coli S17-1 (Wilson et al. 1995) into M. loti JRL501. M. loti JRL501 (pMP2112) and JRL507 were maintained on YM agar plates with $100 \mu \mathrm{M}$ spectinomycin.

\section{Screening of mutants.}

Inbred seeds of L. japonicus 'Gifu' B-129 were mutagenized with $0.4 \%$ EMS for $16 \mathrm{~h}$. After rinsing with distilled water, 8,000 M1 seeds were sown and germinated in Power Soil (Kanto Hiryo Kogyo Co. Ltd., Tokyo) at a density of one plant per $20 \mathrm{~cm}^{2}$. M1 plants were grown in an air-conditioned greenhouse at NIAR, in order to later collect the M2 seeds. Twentynine thousand M2 seeds (10 seeds per seed family) were then sown in vermiculite, watered with nitrogen-free $1 / 2$ nutrient solution (Imaizumi-Anraku et al. 1997), and grown in a greenhouse under a $16-\mathrm{h}$ day/8-h night cycle at $25^{\circ} \mathrm{C}$.

In order to screen for root and root hair mutants, 11,000 M2 seeds (10 seeds per seed family) were aseptically germinated on $0.8 \%$ agar plates containing nitrogen-free B \& D nutrient solution (Broughton and Dilworth 1971) in square plastic plates (Iwaki Co. Ltd., Tokyo). The bottoms of the plates were sealed with black tape, and the sides and tops were wrapped in gas-permeable surgical tape (3M Health Care, St. Paul, MN, U.S.A.). The seedlings were grown under a $16-\mathrm{h}$ day/8-h night cycle at a light intensity of $55 \mu \mathrm{Es}^{-1} \mathrm{~m}^{-2}$ at $22^{\circ} \mathrm{C}$ in a Biotron LH-100 (Nihon-ika Co. Ltd., Tokyo). The plates were oriented vertically to facilitate straight root growth. Three days later, the roots were inoculated with $M$. loti JRL501 or TONO strains at a cell density of $10^{7}$ cells per ml. Putative mutants were screened by visual assay 1 month after inoculation. The inheritance of the mutant phenotype was then followed to the M6 generation.

\section{GUS staining of root nodules.}

Seedling roots (5-mm long) were excised and immersed in $200 \mu \mathrm{l}$ of GUS assay solution ( $0.02 \%$ sodium dodecyl sulfate; $20 \%$ ethanol; $50 \mathrm{mM}$ phosphate buffer, $\mathrm{pH} 7.0$; $0.96 \mathrm{mM} \mathrm{5-}$ bromo-4-chloro-3-indolyl- $\beta$-D-glucuronide [X-Gluc; Wako Pure Chemical Industries Ltd., Osaka, Japan]) in a microfuge tube. After a 10-min vacuum treatment, the samples were incubated overnight at $37^{\circ} \mathrm{C}$. The reaction was stopped by replacing the X-Gluc solution with $70 \%$ ethanol. Nodules and roots infected by $M$. loti JRL507 were viewed under a microscope (SZH10; Olympus Kougaku Co., Tokyo).

\section{Light microscopy.}

Nodules and root segments were fixed overnight in $2 \%$ glutaraldehyde in $0.1 \mathrm{M}$ phosphate buffer $\left(\mathrm{pH} \mathrm{7.2)}\right.$ at $4^{\circ} \mathrm{C}$ and postfixed with $2 \% \mathrm{OsO}_{4}$ for $3 \mathrm{~h}$. The fixed segments were dehydrated through an acetone series to $100 \%$ acetone at room temperature, embedded in Kushida's low-viscosity epoxy resin containing Quetol 651/MNA/DMP-30 (22:28:1) (TABB Laboratories, Berkshire, England), and polymerized at $60^{\circ} \mathrm{C}$ (Imaizumi-Ankaru et al. 1997). Semithin or ultrathin sections were obtained using an ultramicrotome (Reichert Ultracut S; Leica USA, Deerfield, IL, U.S.A.) Serial semithin sections were stained with $1 \%$ toluidine blue in $0.5 \%$ sodium tetraborate ( $\mathrm{pH} 9.0)$ and viewed through an AXIOPLAN light microscope (Carl Zeiss, Stuttgart, Germany).

\section{Allelism tests.}

Reciprocal crossing was carried out according to Jiang and Gresshoff (1997), using $\mathrm{Nod}^{-}$and $\mathrm{Hist}^{-}$mutant categories or Hist $^{-}$and Fix $^{-}$categories. Ljsym8 and Ljsyml6 were used to carry out allelism tests with alb1-1 (Ljsym74-1) and the hypernodulating mutants (Ljsym78-1 and Ljsym78-2), respectively, using mutant lines provided by Jens Stougaard (Schauser et al. 1998).

\section{Effects of nitrate on number of nodules and lateral roots.}

Seeds of the Ljsym78-1 and Ljsym78-2 mutants were germinated on filter paper. Three days later, the seedlings were placed on vermiculite immersed with different concentrations of potassium nitrate and simultaneously inoculated with $M$. loti MAFF 303099 at a cell density of 107 cells per ml. The seedlings were grown under a 16-h day/8-h night cycle at a light intensity of $55 \mu \mathrm{E} \mathrm{s}^{-1} \mathrm{~m}^{-2}$ at $22^{\circ} \mathrm{C}$ in a Biotron LH-100. The number of developing and mature nodules was counted 3 weeks after inoculation. In order to evaluate the number of lateral roots, Ljsym78-1 and Ljsym78-2 mutant seedlings were grown in vermiculite immersed with bacteria-free B \& D medium containing $0.5 \mathrm{mM}$ potassium nitrate for 3 weeks.

\section{ACKNOWLEDGMENTS}

We would like to thank A. Hirsch and R. Ridge for the critical reading of the manuscript and J. Stougaard and H. Spaink for kind gifts of plant symbiotic mutants and bacterial strains. We also thank K. Ohta, T. Minato, E. Kobayashi, Y. Takada, and R. Nishimura for help with genetic analyses and N. Terouchi, T. Aoki, and M. Aoki-Komoto for support of mutant screening. This work was supported by Grant-in-Aid for Scientific Research on Priority Areas (grant 10182102) and special coordination funds for promoting science and technology from the Ministry of Education, Culture, Sports, Science and Technology and from PRESTO, Japan Science and Technology Corporation.

\section{LITERATURE CITED}

Barker, D. G., Bianchi, S., Blondon, F., Dattée, Y., Duc, G., Essad, S., Flament, P., Gallusci, P., Génier, G., Guy, P., Muel, X., Tourneur, J., Dénarié, J., and Huguet, T. 1990. Medicago truncatula, a model plant for studying the molecular genetics of the Rhizobium-legume symbiosis. Plant Mol. Biol. Rep. 8:40-49.

Bénaben, V., Duc, G., Lefebvre, V., and Huguet, T. 1995. TE7, an inefficient mutant of Medicago truncatula Gaertn. cv. Jemalong. Plant Physiol. 107:53-62.

Bonfante, P., Genre, A., Faccio, A., Martini, I., Schauser, L., Stougaard, J., Webb, J., and Parniske, M. 2000. The Lotus japonicus LjSym4 gene is required for the successful symbiotic infection of root epidermal cells. Mol. Plant-Microbe Interact. 13:1109-1120.

Borisov, A. Y., Morzhina, E. V., Kulikova, O. A., Tchetkova, S. A. Lebsky, V. K., and Tikhonovich, I. A. 1992. New symbiotic mutants of pea (Pisum sativum L.) affecting either nodule initiation or symbiosome development. Symbiosis 14:297-313.

Broughton, W. J., and Dilworth, M. Y. 1971. Control of leghemoglobin synthesis in snake beans. Biochem. J. 125:1075-1080.

Caetano-Anolles, G., and Gresshoff, P. M. 1991. Plant genetic control of nodulation. Annu. Rev. Microbiol. 45:345-382.

Catoira, R., Timmers, A. C., Maillet, F., Galera, C., Penmetsa, R. V., Cook, D., Dénarié, J., and Gough, C. 2001. The HCL gene of Medicago truncatula controls Rhizobium-induced root hair curling. Development 128:1507-1508.

Cook, D. R. 1999. Medicago truncatula: A model in the making! Curr. Opin. Plant Biol. 2:301-304.

Dénarié, J., Debellé, F., and Promé, J.-C. 1996. Rhizobium lipo-chitooligosaccharide nodulation factors: Signaling molecular mediating recognition and morphogenesis. Annu. Rev. Biochem. 65:503-535.

Devine, T. E., and Kuykendall, L. D. 1996. Host genetic control of symbiosis in soybean (Glycine max L.). Plant Soil 186:173-187.

Duc, G. 1995. Mutagenesis of fava bean (Vicia faba L.) and the identification of five different genes controlling no nodulation, ineffective nodulation, or supernodulation. Euphytica 83:147-152.

Duc, G., and Messager, A. 1989. Mutagenesis of pea (Pisum sativum L.) and the isolation of mutants for nodulation and nitrogen fixation. Plant Sci. 60:207-213.

Dudley, M. E., and Long, S. R. 1989. A non-nodulating alfalfa mutant displays neither root hair curling nor early cell division in response to Rhizobium meliloti. Plant Cell 1:65-72.

Fischer, H. M. 1994. Genetic regulation of nitrogen fixation in rhizobia. Microbiol. Rev. 58:352-386.

Gonzalez, J. E., York, G. M., and Walker, G. C. 1996. Rhizobium meliloti 
exopolysaccharides: Synthesis and symbiotic function. Gene 179:141146

Handberg, K., and Stougaard, J. 1992. Lotus japonicus, diploid legume species for classical and molecular genetics. Plant J. 2:487-496.

Handberg, K., Stiller, J., Thykjær, T., and Stougaard, J. 1994. Transgenic plants: Agrobacterium-mediated transformation of diploid legume Lotus japonicus. Pages 119-128 in: Cell Biology: Laboratory Handbook. J. E. Celis, ed. Academic Press, New York.

Hardtke, C. S., Gohda, K., Osterlund, M. T., Oyama, T., Okada, K., and Deng, X. W. 2000. HY5 stability and activity in Arabidopsis is regulated by phosphorylation in its COP1 binding domain. EMBO (Eur. Mol. Biol. Organ.) J. 19:4997-5006.

Haser, A., Robinson, D. L., Duc, G., and Vance, C. P. 1992. A mutation in Vicia faba results in ineffective nodules with impaired bacteroid differentiation and reduced synthesis of late nodulin. J. Exp. Bot. 43:13971407.

Hayashi, M., Imaizumi-Anraku, H., Akao, S., and Kawaguchi, M. 2000 Nodule organogenesis in Lotus japonicus. J. Plant Res. 113:489-496.

Heidstra, R., Yang, W. C., Yalcin, Y., Peck, S., Emons, A., van Kammen, A., and Bisseling, T. 1997. Ethylene provides positional information on cortical cell division but is not involved in Nod factor-induced root hair tip growth in Rhizobium-legume interaction. Development 124:1781-1787.

Hirsch, A. M. 1992. Developmental biology of legume nodulation. New Phytol. 122:211-237.

Imaizumi-Anraku, H., Kawaguchi, M., Koiwa, H., Akao, S., and Syono, K. 1997. Two ineffective-nodulating mutants of Lotus japonicus. Different phenotypes caused by the blockage of endocytotic bacterial release and nodule maturation. Plant Cell Physiol. 38:871-881.

Imaizumi-Anraku, H., Kouchi, H., Syono, K., Akao, S., and Kawaguchi, M. 2000. Analysis of ENOD40 expression in alb1, a symbiotic mutant of Lotus japonicus that forms empty nodules with incompletely developed nodule vascular bundles. Mol. Gen. Genet. 264:402-410.

Jacobsen, E., and Feenstra, W. J. 1984. A new pea mutant with efficient nodulation in the presence of nitrate. Plant Sci. Lett. 33:337-344.

Jiang, Q., and Gresshoff, P. M. 1997. Classical and molecular genetics of the model legume Lotus japonicus. Mol. Plant-Microbe Interac. 10:5968 .

Kawaguchi, M. 2000. Lotus japonicus 'Miyakojima' MG-20: An earlyflowering accession suitable for indoor handling. J. Plant Res. 113:507-509.

Kawaguchi, M., Motomura, T., Imaizumi-Anraku, H., Akao, S., and Kawasaki, S. 2001. Providing the basis for genomics in Lotus japonicus: The accessions Miyakojima and Gifu are appropriate crossing partners for genetic analyses. Mol. Gen. Genom. 266:157-166.

Kneen, B. E., and La Rue, T. A. 1988. Induced symbiosis mutants of pea (Pisum sativum) and sweet clover (Melilotus alba). Plant Sci. 58:177182.

Kneen, B. E., Weeden, N. F., and La Rue, T. A. 1994. Non-nodulating mutants of Pisum sativum (L.) cv. Sparkle. J. Hered. 85:129-133.

Long, S. R. 1996. Rhizobium symbiosis: Nod factors in perspective. Plant Cell 8:1885-1898.

López-Lara, I. M., van den Berg, J. D. J., Thomas Oates, J. E., Glushka, J., Lugtenberg, B. J. J., and Spaink, H. P. 1995. Structural identification of the lipo-chitin oligosaccharide nodulation signals of Rhizobium loti. Mol. Microbiol. 15:627-638.

Martirani, L., Stiller, J., Mirabella, R., Alfano, F., Lamberti, A., Radutoiu, S. E., Iaccarino, M., Gresshoff, P. M., and Chiurazzi, M. 1999. T-DNA tagging of nodulation- and root-related genes in Lotus japonicus: Expression patterns and potential for promoter trapping and insertional mutagenesis. Mol. Plant-Microbe Interact. 12:275-284.

Men, A. E., Meksem, K., Kassem, M. A., Lohar, D., Stiller, J., Lightfoot, D., and Gresshoff, P. M. 2001. A bacterial artificial chromosome library of Lotus japonicus constructed in an Agrobacterium tumefaciens-transformable vector. Mol. Plant-Microbe Interact. 14:422-425.

Morzhina, E. V., Tsyganov, V. E., Borisov, A. Y., Labsky, V. K., and Tikhonovich, I. A. 2000. Four developmental stages identified by genetic dissection of pea (Pisum sativum L.) root nodule morphogenesis. Plant Sci. 155:75-83.

Niwa, S., Kawaguchi, M., Imaizumi-Anraku, H., Chechetka, S. A. Ishizaka, M., Ikuta, A., and Kouchi, H. 2001. Responses of a model legume Lotus japonicus to lipochitin oligosaccharide nodulation factors purified from Mesorhizobium loti JRL501. Mol. Plant-Microbe Interact. 14:848-856.

Oger, P., Petit, A., and Dessaux, Y. 1996. A simple technique for direct transformation and regeneration of the diploid legume species Lotus japonicus. Plant Sci. 116:159-168.

Oyama, T., Shimura, Y., and Okada, K. 1997. The Arabidopsis HY5 gene encodes a bZIP protein that regulates stimulus-induced development of root and hypocotyl. Genes Dev. 11:2983-2995.

Park, S. J., and Buttery, B. R. 1988. Nodulation mutants of white bean (Phaseolus vulgaris L.) induced by ethylmethane sulphonate. Can. J. Plant Sci. 68:199-202.

Park, S. J., and Buttery, B. R. 1994. Inheritance of non-nodulation and ineffective nodulation mutants in common bean (Phaseolus vurgaris L.) J. Hered. 85:1-3.

Penmetsa, R. V., and Cook, D. R. 1997. A legume ethylene-insensitive mutant hyperinfected by its rhizobial symbiont. Science 275:527-530.

Sagan, M., Morandi, D., Tarenghi, E., and Duc, G. 1995. Selection of mycorrhizal mutants in the model plant Medicago truncatula (Gaertn.) after-ray mutagenesis. Plant Sci. 111:63-71.

Sandal, N. N., and Stougaard, J. 1998. A Lotus filicaulis $\times$ L. japonicus F2 population for genetic and physical mapping. Page 325 in: Biological Nitrogen Fixation for the 21st Century. C. Elmerich, A Kondorosi, and W. E. Newton, eds. Kluwer Academic Publishers, Dordrecht, The Netherlands.

Schauser, L., Handberg, K., Sandal, N., Stiller, J., Thykjær, T., Pajuelo, E., Nielsen, A., and Stougaard, J. 1998. Symbiotic mutants deficient in nodule establishment identified after T-DNA transformation of Lotus japonicus. Mol. Gen. Genet. 259:414-423.

Schauser, L., Roussis, A., Stiller, J., and Stougaard, J. 1999. A plant regulator controlling development of symbiotic root nodules. Nature 402:191-195

Schneider, K., Wells, B., Dolan, L., and Roberts, K. 1997. Structural and genetic analysis of epidermal cell differentiation in Arabidopsis primary roots. Development 124:1789-1798.

Schultze, M., and Kondorosi, A. 1998. Regulation of symbiotic root nodule development. Annu. Rev. Genet. 32:33-57.

Senoo, K., Solaiman, M. Z., Kawaguchi, M., Imaizumi-Anraku, H., Akao, S., Tanaka, A., and Obata, H. 2000. Isolation of two different phenotypes of mycorrhizal mutants in the model legume plant Lotus japonicus after EMS-treatment. Plant Cell Physiol. 41:726-732.

Solaiman, M. Z., Senoo, K., Kawaguchi, M., Imaizumi-Anraku, H. Akao, S., Tanaka, A., and Obata, H. 2000. Characterization of mycorrhizas formed by Glomus sp. on root of hypernodulating mutants of Lotus japonicus. J. Plant Res. 113:443-448.

Spaink, H. P. 1992. Rhizobial lipooligosaccharides: Answers and questions. Plant Mol. Biol. 20:977-986.

Spaink, H. P., and Lugtenberg, B. J. J. 1994. Role of rhizobial lipo-chitin oligosacharide signal molecules in root nodule organogenesis. Plant Mol. Biol. 26:1413-1422.

Stiller, J., Martirani, L., Tuppale, S., Chian, R. J., Chiurazzi, M., and Gresshof, P. M. 1997. High frequency transformation and regeneration of transgenic plants in model legume Lotus japonicus. J. Exp. Bot. 48:1357-1365

Stougaard, J. 2001. Genetics and genomics of root symbiosis. Curr. Opin. Plant Biol. 4:328-335.

Suganuma, N. 1999. Host-control genes affecting nitrogen fixing activity in legume nodules. Curr. Top. Plant Biol. 1:145-149.

Szczyglowski, K., Shaw, R. S., Wopereis, J., Copeland, S., Hamburger, D., Kasiborski, B., Dazzo, F. B., and de Bruijn, F. J. 1998. Nodule organogenesis and symbiotic mutants of model legume Lotus japonicus. Mol. Plant-Microbe Interact. 11:684-697.

Thykjær, T., Stiller, J., Handberg, K., Jones, J., and Stougaard, J. 1995. The maize transposable element $A c$ is mobile in the legume Lotus japonicus. Plant Mol. Biol. 27:981-993.

Tirichine, L., de Billy, F., and Huguet, T. 2000. Mtsym6, a gene conditioning Sinorhizobium strain-specific nitrogen fixation in Medicago truncatula. Plant Physiol. 123:845-852.

Vasse, J., de Billy, F., and Truchet, G. 1993. Abortion of infection during the Rhizobium meliloti-alfalfa symbiotic interaction is accompanied by a hypersensitive reaction. Plant J. 4:555-566.

Wegel, E., Schauser, L., Sandal, N., Stougaard, J., and Parniske, M. 1998. Mycorrhiza mutants of Lotus japonicus define genetically independen steps during symbiotic infection. Mol. Plant-Microbe Interact. 11:933936.

Wilson, K. J., Sessitsch, A., Corbo, J. C., Giller, K. E., Akkermans, A. D. L., and Jefferson, R. A. 1995. Glucronidase (GUS) transposons for ecological and genetic studies of rhizobia and other gram-negative bacteria. Microbiology 141:1691-1705.

Wopereis, J., Pajuelo, E., Dazzo, F. B., Jiang, Q., Gresshoff, P. M., De Bruijn, F. J., Stougaard, J., and Szczyglowski, K. 2000. Short root mutant of Lotus japonicus with a dramatically altered symbiotic phenotype. Plant J. 23:97-114. 